\title{
THE JURISPRUDENCE OF ADVERSARIAL JUSTICE
}

\author{
Ikenga K.E.Oraegbunam* \\ http://dx.doi.org/10.4314/og.v15i1.2
}

\begin{abstract}
The adversarial system of justice works to resolve cases in court by pitting partial advocates for each side against one another with a judge who works to ensure that the rules of court and law are followed. The system thrives by its use of interested opposing parties debating over an issue in order to ensure the pursuit of justice. This system of justice delivery has been criticized for its value of winning over truth, but studies show it is a system that looks to protect the rights of individuals on trial. This paper examines the operation of the system in general and juxtaposes it with the opposing inquisitorial approach that renders the judge also an investigator. The paper equally studies how the system works in Nigeria and evaluates its results.
\end{abstract}

Keywords: Adversarial, Inquisitorial, Justice System, Nigeria, Judiciary

\section{Introduction}

The characteristic of a good state is that it exists for the good of the people who formed it. Though Locke placed the sovereignty on the people via the legislature, he nevertheless posited that arbitrary laws, alteration of election, foreign power and neglect of enacted law can destroy a state (Locke, 1960). These last items bring to mind the status and imperative of the judiciary and a judicial system. Indeed, the most important aspect of modern democracies is the judiciary; this is because, it interprets whatever law that underlies what is to be done and adjudicates when it is finally done nay poorly or wrongly. This onerous, critical and principal task of the judiciary is carried out through the help of a judicial system. The judicial system has the framework and the structure that enables the smooth running of the state. The Anglo Saxon scholars sought for this so that peace will reign in the society. The outcome of their activity was the enthronement of two major judicial systems; the inquisitorial system and the adversarial system. This work however is concerned with the 
adversarial system. This paper intends to analyse this judicial system in view of attempting to understand its schemes and also its major challenges.

\section{The Judicial/Justice System}

The judicial system is the system of law courts that administer justice and constitute the judicial branch of government. The judiciary (also known as the judicial system or court system) is the system of courts that interprets and applies the law in the name of the state. The judiciary also offers the requisite schemes, procedure and process for the resolution of disputes. In some nations, under doctrines of separation of powers, the judiciary does not necessarily make or enforce the law; rather it interprets law and applies it to the facts of each case. In other nations, the judiciary can indeed make law, this is known as the Common Law and it sets the pattern for other judges to follow. Most often than not, the foremost preoccupation of the Judiciary is to ensure and assure the people of their equality before the laws of the land (Cooper, 2010). In many settings the judiciary is empowered to change laws through a judicial review process. Courts with judicial review power can annul states' laws and rules when it conflicts with a higher norm, like; the primary legislation, the provisions of the constitution or international law. The importance of the Judiciary in any political system cannot be over-emphasized; hence the constitution provides for its full independence to enable it perform its sacred constitutional function without sentiments and reservations (Akpuru-Aja, 1999).

In the judicial system, Judges are the ones who interpret and implement the constitution. For a people to establish and keep the 'Rule of Law' as the operative norm in social constructs great care must be taken in the election and/or appointment of unbiased and thoughtful legal scholars whose loyalty to an oath of office is without reproach. If law is to govern and find acceptance generally, courts must exercise fidelity to justice which means affording those subject to its jurisdictional scope the greatest presumption of inherent cultural relevance within this framework (Mauro, 1967). In the US during recent decades the judiciary became active in economic issues related with economic rights established by constitution because, economics may provide insight into questions that bear on the proper legal interpretation. Since many countries 
Oraegbunam: The Jurisprudence of Adversarial Justice

with transitional political and economic systems continue treating their constitutions as abstract legal documents disengaged from the economic policy of the state, practice of judicial review of economic acts of executive and legislative branches have begun to grow (Posner, 1982).

\section{The Adversarial System}

The adversarial system or adversary system is a legal system used in the common law countries where two advocates represent their parties' positions before an impartial person or group of people, usually a jury or judge, who attempt to determine the truth of the case. This system is in sharp contrast to the inquisitorial system used in some civil law systems (i.e. those deriving from Roman law or the Napoleonic code) where a judge or group of judges investigates the case. The adversarial system is the two-sided structure under which criminal trial courts operate that pits the prosecution against the defense. Justice is done when the most effective adversary is able to convince the judge or jury that his or her perspective on the case is the correct one. The prosecutor tries to prove the defendant is guilty, and the defendant's attorney argues for the defendant's acquittal. The case is then decided by a judge (or a jury) who does not investigate the facts but acts as an umpire (DeBarna, 2002). It is also called the accusatorial procedure. It is the judicial system of trial in English legal system (practiced in Great Britain, most commonwealth countries, and the US except the US state of Louisiana, and Canada's Quebec province). In this system, the role of the judge is to ensure the trial proceeds according to the procedural rules of trial or due process of law and that evidence entered is done so according to established rules and guidelines.

In an adversary system, the judge or jury is a neutral and passive fact finder, dispassionately examining the evidence presented by the parties with the objective of resolving the dispute between them. The fact finder must remain uninvolved in the presentation of arguments so as to avoid reaching a premature decision. Even the Australian courts use the adversary system of trial when resolving disputes. It is a system based on the notion of two adversaries battling in an arena before an impartial third party, with the emphasis on winning. Historically, some writers trace the process to the medieval mode of trial by combat, in which some 
litigants, notably women, were allowed a champion to represent them (Strick, 1977:21). The use of the jury in the common law system seems to have fostered the adversarial system and provides the opportunity for both sides to argue their point of view. The name 'adversarial system' may be misleading in that it implies it is only within this type of system in which there are opposing prosecution and defense. This is not the case, as both modern adversarial and inquisitorial systems have the powers of the state separated between a prosecutor and the judge and allow the defendant the right to counsel.

Indeed, the European Convention on Human Rights and Fundamental Freedoms in Article 6 requires these features in the legal systems of its signatory states. The right to counsel in criminal trials was initially not accepted in some adversarial systems. It was believed that the facts should speak for themselves, and that lawyers would just blur the matters. As a consequence, it was only in 1836 that England gave suspects of felonies the formal right to have legal counsel (the Prisoners' Counsel Act 1836), although in practise English courts routinely allowed defendants to be represented by counsel from the mid-18th century. During the second half of the 18th century advocates like Sir William Garrow and Thomas Erskine, 1st Baron Erskine helped usher in the adversarial court system used in most common law countries today. In the United States, however, personally retained counsel have had a right to appear in all federal criminal cases since the adoption of the Constitution and in state cases at least since the end of the Civil War, although nearly all provided this right in their state constitutions or laws much earlier.

Appointment of counsel for indigent defendants was nearly universal in federal felony cases, though it varied considerably in state cases. It was not until 1963 that the U.S. Supreme Court declared that legal counsel must be provided at the expense of the state for indigent felony defendants, under the federal Sixth Amendment, in state courts (Robert, 2003). In some adversarial legislative systems, the court is permitted to make inferences on an accused's failure to face cross-examination or to answer a particular question. This obviously limits the usefulness of silence as a tactic by the defense. In England, the Criminal Justice and Public Order Act 1994 allowed such inferences to be made for the first time in 
England and Wales (it was already possible in Scotland under the rule of criminative circumstances). This change was disparaged by critics as an end to the 'right to silence', though in fact an accused still has the right to remain silent and cannot be compelled to take the stand. The criticism reflects the idea that if the accused can be inferred to be guilty by exercising their right to silence, it no longer confers the protection intended by such a right. In the United States, the Fifth Amendment has been interpreted to prohibit a jury from drawing a negative inference based on the defendant's invocation of his right not to testify, and the jury must be so instructed if the defendant requests (Wikipedia, 2016).

The basis of this approach in criminal matters is that two sides engage in debate and battle about the guilt or innocence of an accused and each side wants to win, then the debate will foster a critical look at the issues and the calling of evidence to be examined by both parties. By engaging in this discourse, the truth should emerge as the judge watches on. This means that the roles played by the various court officers are very distinct. The defence counsel as one adversarial party gathers the arguments to defend the client and attacks the credibility and worthiness of the evidence presented by the crown. The crown prosecutor puts forth the arguments on behalf of the crown or state and gathers and presents the evidence pointing that the accused has committed an offence. The judge is the referee and arbitrator on issues related to clarifying what the law is. The judge does not intervene on any side except where procedural fairness is jeopardized by either party. The evidence and witnesses that are called are left up to the two arguing parties, the defence counsel and the crown. The judge is not involved in what is presented to the court. If the crown wishes not to call certain evidence or individuals as witnesses even though it may help shed light on the case, the judge cannot intervene. This leaves the two parties in charge of the case and the direction it takes; this appears to be one of the beauties of this system

\section{Features of the Adversary Judicial System}

Role of the parties: The two adversarial parties have full control over proceedings. That is, they are responsible for pre-trial procedures, and preparation and presentation of their respective 
cases. They must gather evidence, organise witnesses and employ experts. On a procedural level, they are also responsible for determining the time and place of the hearing. This role ensures that parties have the ability to present the best case possible.

Role of the judge: The judge's main role is to control proceedings and ensure that rules of evidence and procedure are followed. This means that a judge decides what evidence is admissible, inadmissible, and which is to be excluded from the trial. At the conclusion of the two parties' presentations, a judge will instruct the jury if there is one, summing up the case and instructing them of the relevant law to be followed. With or without a jury, the judge decides the relevant law to be applied. However, when there is no jury, the judge decides on questions of fact. That is the judge determines which presentation of evidence is more persuasive and truthful, before reaching a verdict. The judge always decides on the sanction (in criminal cases) or remedy (in civil cases).

Rules of evidence and procedure: Rules of evidence and procedure are strict in the adversary system of trial, and aim to ensure that the trial is fair and unbiased and that parties have an equal opportunity to present their case. The rules of evidence are also developed based upon the system of objections of adversaries and on what basis it may tend to prejudice the trier of fact which may be the judge or the jury. In a way the rules of evidence can function to give a judge limited inquisitorial powers as the judge may exclude evidence that is not trustworthy or irrelevant to the legal issue at hand. All evidence must be relevant and not hearsay evidence. Some rules of evidence are:

- That only certain types of evidence are admissible, and others are inadmissible

- Only relevant and reliable evidence is allowed. This can come in the form of oral, documentary or expert evidence

- Inadmissible evidence includes hearsay evidence, and evidence that has been obtained unlawfully

- These rules ensure that parties are treated fairly 
Oraegbunam: The Jurisprudence of Adversarial Justice

Some rules of procedure are:

- A hearing is to be single and continuous

- Questioning stages are organised strictly

- Delays will occur but are ideally minimised

Standard and burden of proof: The burden of proof refers to who has the responsibility to prove their case in court. In criminal proceedings, the prosecution must prove the defendant's guilt, and in civil proceedings, the plaintiff must prove that the defendant was liable. Standard of proof refers to the level of convincing required to prove a case. In criminal cases, the prosecution must prove that the defendant is guilty "beyond reasonable doubt". In civil cases, the plaintiff must prove that the defendant infringed their rights on the "balance of probabilities" i.e. it is more likely than not that the defendant was in the wrong.

Need for legal representation: Often, the responsibility of preparing and presenting one's own case is delegated to legal representation, and a party will be disadvantaged without it. Solicitors handle most of the pre-trial preparation, while a barrister conducts the trial presentation, including questioning of witnesses. Legal representatives are vital in assisting the parties. They understand the complex rules involved in bringing a case to court that an ordinary citizen may not, and are therefore able to ensure that a party's case is prepared and presented in the best possible manner.

As an accused is not compelled to give evidence in a criminal adversarial proceeding, they may not be questioned by a prosecutor or judge unless they choose to do so. However, should they decide to testify, they are subject to cross-examination and could be found guilty of perjury. As the election to maintain an accused person's right to silence prevents any examination or cross-examination of that person's position, it follows that the decision of counsel as to what evidence will be called is a crucial tactic in any case in the adversarial system and hence it might be said that it is a lawyer's manipulation of the truth. Certainly, it requires the skills of counsel on both sides to be fairly equally 
pitted and subjected to an impartial judge. By contrast, while defendants in most civil law systems can be compelled to give a statement, this statement is not subject to cross-examination by the prosecutor and not given under oath. This allows the defendant to explain his side of the case without being subject to crossexamination by a skilled opposition. However, this is mainly because it is not the prosecutor but the judges who question the defendant. The concept of 'cross'-examination is entirely due to adversarial structure of the common law.

\section{A Thematic Analysis of the Adversarial and the Inquisitorial Judicial Systems}

\begin{tabular}{|c|c|c|}
\hline Issues & adversarial systems & $\begin{array}{l}\text { inquisitorial } \\
\text { systems }\end{array}$ \\
\hline $\begin{array}{l}\text { Binding } \\
\text { force of case } \\
\text { law }\end{array}$ & $\begin{array}{l}\text { Previous decisions by } \\
\text { higher courts are binding } \\
\text { on lower courts }\end{array}$ & $\begin{array}{l}\text { Traditionally, there } \\
\text { is little use of } \\
\text { judicial precedent. } \\
\text { This means Judges } \\
\text { are free to decide } \\
\text { each case } \\
\text { independently of } \\
\text { previous decisions, } \\
\text { by applying the } \\
\text { relevant } \\
\text { statutes. There is } \\
\text { therefore heavier } \\
\text { reliance on } \\
\text { comprehensive } \\
\text { statutes/codes of } \\
\text { law. The typical } \\
\text { criminal proceeding } \\
\text { is divided into } 3 \\
\text { phases: the } \\
\text { investigate phase, } \\
\text { the examining } \\
\text { phase, and the trial. }\end{array}$ \\
\hline Investigation & The responsibility & In the investigative \\
\hline
\end{tabular}


Oraegbunam: The Jurisprudence of Adversarial Justice

\begin{tabular}{|c|c|c|}
\hline & $\begin{array}{l}\text { gathering evidence rests } \\
\text { with the parties (the } \\
\text { Police and the defence). }\end{array}$ & $\begin{array}{l}\text { phase, } \\
\text { government official } \\
\text { (the public } \\
\text { prosecutor) collects } \\
\text { evidence and } \\
\text { decides whether to } \\
\text { press } \\
\text { charges. Prosecutors } \\
\text { carry out } \\
\text { investigations } \\
\text { themselves } \\
\text { request Police to do } \\
\text { so. The prosecution } \\
\text { can give general } \\
\text { instructions to the } \\
\text { Police regarding } \\
\text { how particular cases } \\
\text { are to be handled } \\
\text { and can set areas of } \\
\text { priority for } \\
\text { investigations. In } \\
\text { some inquisitorial } \\
\text { systems, a Judge } \\
\text { may carry out or } \\
\text { oversee the } \\
\text { investigative phase. }\end{array}$ \\
\hline $\begin{array}{l}\text { Examining } \\
\text { phase }\end{array}$ & $\begin{array}{l}\text { There is no examination } \\
\text { phase, so an } \\
\text { independent evaluation } \\
\text { of the evidence } \\
\text { collected during } \\
\text { investigation is left to } \\
\text { the trial. }\end{array}$ & $\begin{array}{l}\text { The examining } \\
\text { phase is usually } \\
\text { conducted in } \\
\text { writing. An } \\
\text { examining Judge } \\
\text { completes and } \\
\text { reviews the written } \\
\text { record and decides } \\
\text { whether the case } \\
\text { should proceed to } \\
\text { trial. The examining } \\
\text { Judge plays an }\end{array}$ \\
\hline
\end{tabular}


Ogirisi: a new journal of African studies vol. 152019

\begin{tabular}{|c|c|c|}
\hline & & $\begin{array}{l}\text { active role in the } \\
\text { collection of } \\
\text { evidence and } \\
\text { interrogation of } \\
\text { witnesses. In some } \\
\text { inquisitorial } \\
\text { systems, the } \\
\text { "legality principle" } \\
\text { dictates that } \\
\text { prosecution must } \\
\text { take place in all } \\
\text { cases in which } \\
\text { sufficient evidence } \\
\text { exists (ie, the } \\
\text { prosecutor or Judge } \\
\text { has limited } \\
\text { discretion as to } \\
\text { whether or not } \\
\text { charges will be } \\
\text { brought). }\end{array}$ \\
\hline The trial & $\begin{array}{l}\text { An adversarial system } \\
\text { requires the prosecutor, } \\
\text { acting on behalf of the } \\
\text { State, and the defence } \\
\text { lawyer, acting on behalf } \\
\text { of the accused, to offer } \\
\text { their version of events } \\
\text { and argue their case } \\
\text { before an impartial } \\
\text { adjudicator (a Judge } \\
\text { and/or jury). Each } \\
\text { witness gives their } \\
\text { evidence-in-chief (orally) } \\
\text { and may be cross- } \\
\text { examined by opposing } \\
\text { counsel and re-examined } \\
\text { ((In New Zealand, } \\
\text { defendants have the right }\end{array}$ & $\begin{array}{l}\text { As a result of the } \\
\text { thoroughness of the } \\
\text { examining phase, a } \\
\text { record of evidence } \\
\text { has already been } \\
\text { made and is equally } \\
\text { available to the } \\
\text { prosecution and } \\
\text { defence well in } \\
\text { advance of the trial. } \\
\text { The main function } \\
\text { of a trial is to } \\
\text { present the case to } \\
\text { the trial Judge and, } \\
\text { in some cases, the } \\
\text { jury, and to allow } \\
\text { the lawyers to } \\
\text { present }\end{array}$ \\
\hline
\end{tabular}




\begin{tabular}{|c|c|c|}
\hline & $\begin{array}{l}\text { to examine the witnesses } \\
\text { for the prosecution under } \\
\text { section } 25(\mathrm{f}) \text { of the New } \\
\text { Zealand Bill of Rights } \\
\text { Act 1990). }\end{array}$ & $\begin{array}{l}\text { argument in public. } \\
\text { While there is no } \\
\text { cross- and re- } \\
\text { examination of } \\
\text { witnesses, witnesses } \\
\text { are still questioned } \\
\text { and challenged. In } \\
\text { Germany there is a } \\
\text { preference for } \\
\text { narrative testimony, } \\
\text { in which the witness } \\
\text { gives their version } \\
\text { of events without } \\
\text { shaping by } \\
\text { questions from the } \\
\text { prosecution or } \\
\text { defence } \\
\text { 1996). } \\
\text { Traditionally there } \\
\text { is no ability for the } \\
\text { defendant to plead } \\
\text { guilty. }\end{array}$ \\
\hline $\begin{array}{l}\text { Role of the } \\
\text { trial Judge } \\
\text { and counsel }\end{array}$ & $\begin{array}{l}\text { The Judge is a referee } \\
\text { at the hearing. It is the } \\
\text { Judge's function to } \\
\text { ensure that the court } \\
\text { case is conducted in a } \\
\text { manner that observes } \\
\text { due process. The } \\
\text { Judge decides whether } \\
\text { the defendant is guilty } \\
\text { beyond reasonable } \\
\text { doubt (except in jury } \\
\text { trials where the jury } \\
\text { performs that role), and } \\
\text { determines the } \\
\text { sentence. Lawyers are }\end{array}$ & $\begin{array}{l}\text { Judges are required } \\
\text { to direct the } \\
\text { courtroom debate } \\
\text { and to come to a } \\
\text { final decision. The } \\
\text { Judge assumes the } \\
\text { role of principal } \\
\text { interrogator of } \\
\text { witnesses and the } \\
\text { defendant, and is } \\
\text { under an obligation } \\
\text { to take evidence } \\
\text { until he or she } \\
\text { ascertains the truth. } \\
\text { It is the Judge that }\end{array}$ \\
\hline
\end{tabular}


Ogirisi: a new journal of African studies vol. 152019

\begin{tabular}{|c|c|c|}
\hline & $\begin{array}{lr}\text { primarily } & \text { responsible } \\
\text { for } & \text { introducing } \\
\text { evidence } & \text { and } \\
\text { questioning } & \text { witnesses }\end{array}$ & $\begin{array}{l}\text { carries out most of } \\
\text { the examination of } \\
\text { witnesses, arising } \\
\text { from their } \\
\text { obligation to inquire } \\
\text { into the charges and } \\
\text { to evaluate all } \\
\text { relevant evidence in } \\
\text { reaching their } \\
\text { decision (Pizzi, } \\
\text { 1996). However, it } \\
\text { is now accepted that } \\
\text { the defence should } \\
\text { have the right to } \\
\text { confront each } \\
\text { witness during at } \\
\text { least one stage in } \\
\text { the proceedings } \\
\text { (Spencer, 2002). }\end{array}$ \\
\hline Use of juries & $\begin{array}{l}\text { Juries are used in many } \\
\text { cases. In New Zealand, if } \\
\text { the maximum sentence } \\
\text { of the charge is more } \\
\text { than three months, the } \\
\text { defendant has the right to } \\
\text { elect trial by jury (This is } \\
\text { provided by section 24(e) } \\
\text { of the New Zealand Bill } \\
\text { of Rights Act } \\
\text { 1990. However, there is } \\
\text { a proposal in the } \\
\text { Criminal Procedure } \\
\text { (Reform and } \\
\text { Modernisation) Bill to } \\
\text { change this to three } \\
\text { years.). Evidence which } \\
\text { is prejudicial or of little } \\
\text { probative value, is more }\end{array}$ & $\begin{array}{l}\text { Juries are generally } \\
\text { only used for the } \\
\text { most serious cases. }\end{array}$ \\
\hline
\end{tabular}




\begin{tabular}{|c|c|c|}
\hline & $\begin{array}{l}\text { likely to be withheld } \\
\text { from juries (who don't } \\
\text { have training on the } \\
\text { weight that should be } \\
\text { given to certain } \\
\text { evidence). However, } \\
\text { hearsay evidence is more } \\
\text { readily allowable if it is } \\
\text { reliable. }\end{array}$ & \\
\hline $\begin{array}{ll}\text { Rules } & \text { of } \\
\text { Evidence } & \end{array}$ & $\begin{array}{l}\text { Evidence which is } \\
\text { prejudicial or of little } \\
\text { probative value, is more } \\
\text { likely to be withheld } \\
\text { from juries (who don't } \\
\text { have training on the } \\
\text { weight that should be } \\
\text { given to certain } \\
\text { evidence). However, } \\
\text { hearsay evidence is more } \\
\text { readily allowable if it is } \\
\text { reliable. A significant } \\
\text { category of inadmissible } \\
\text { evidence is 'hearsay' } \\
\text { evidence (with numerous } \\
\text { exceptions). In New } \\
\text { Zealand, a 'hearsay } \\
\text { statement' is defined in } \\
\text { the Evidence Act } 2006 \text { as } \\
\text { "a statement that was } \\
\text { made by a person other } \\
\text { than a witness and is } \\
\text { offered in evidence at the } \\
\text { proceedings to prove the } \\
\text { truth of its contents". At } \\
\text { the heart of the hearsay } \\
\text { rule is the idea that, if the } \\
\text { court is to discover the } \\
\text { truth, it is essential that }\end{array}$ & $\begin{array}{l}\text { The rules around } \\
\text { admissibility of } \\
\text { evidence are } \\
\text { significantly more } \\
\text { lenient. The } \\
\text { absence of juries in } \\
\text { many cases } \\
\text { alleviates the need } \\
\text { for many formal } \\
\text { rules of } \\
\text { evidence. More } \\
\text { evidence is likely to } \\
\text { be admitted, } \\
\text { regardless of its } \\
\text { reliability or } \\
\text { prejudicial ing } \\
\text { effect. Evidence is } \\
\text { admitted if the } \\
\text { Judge decides it is } \\
\text { relevant. In many } \\
\text { inquisitorial } \\
\text { systems, there is no } \\
\text { hearsay rule (eg, } \\
\text { France, Belgium } \\
\text { and Germany). It is } \\
\text { up to the Judge to } \\
\text { decide the value of } \\
\text { such testimony. }\end{array}$ \\
\hline
\end{tabular}


Ogirisi: a new journal of African studies vol. 152019

\begin{tabular}{|c|c|c|}
\hline & $\begin{array}{l}\text { parties have the } \\
\text { opportunity to verify the } \\
\text { information provided by } \\
\text { the witnesses, which is } \\
\text { difficult to do if the court } \\
\text { receives evidence in } \\
\text { writing or via a third } \\
\text { party (and are therefore } \\
\text { unable to cross-examine } \\
\text { the person). }\end{array}$ & \\
\hline $\begin{array}{l}\text { Rights of the } \\
\text { defendant }\end{array}$ & $\begin{array}{l}\text { The accused is } \\
\text { protected from self- } \\
\text { incrimination and } \\
\text { guaranteed the right to } \\
\text { a fair trial. But, some } \\
\text { view adversarial } \\
\text { systems as offering } \\
\text { stronger protections for } \\
\text { defendants due to their } \\
\text { interpretation of the } \\
\text { right to silence. }\end{array}$ & $\begin{array}{l}\text { The accused is } \\
\text { protected from self- } \\
\text { incrimination and } \\
\text { guaranteed the right } \\
\text { to a fair trial. }\end{array}$ \\
\hline $\begin{array}{l}\text { Role of the } \\
\text { Victim }\end{array}$ & $\begin{array}{l}\text { Victims are not a party to } \\
\text { proceedings. Prosecutors } \\
\text { act on behalf of the State } \\
\text { and do not represent the } \\
\text { victim. In New Zealand, } \\
\text { victims can provide a } \\
\text { victim impact statement } \\
\text { to the court at } \\
\text { sentencing, which the } \\
\text { Judge must take into } \\
\text { account when } \\
\text { determining the } \\
\text { offender's sentence. }\end{array}$ & $\begin{array}{l}\text { The victim } \\
\text { generally has a } \\
\text { more recognised } \\
\text { role in inquisitorial } \\
\text { systems - they } \\
\text { usually have the } \\
\text { status of a party to } \\
\text { proceedings. In } \\
\text { some jurisdictions, } \\
\text { victims have a } \\
\text { formal role in the } \\
\text { pre-trial } \\
\text { investigative stage, } \\
\text { including a } \\
\text { recognised right to } \\
\text { request particular } \\
\text { lines of inquiry or to }\end{array}$ \\
\hline
\end{tabular}




\begin{tabular}{|l|l|l|}
\hline & & $\begin{array}{l}\text { participate in } \\
\text { interviews by the } \\
\text { investigating } \\
\text { authority. At the } \\
\text { trial, they generally } \\
\text { have independent } \\
\text { standing and some } \\
\text { jurisdictions allow } \\
\text { victims to be } \\
\text { represented by their } \\
\text { own lawyer. }\end{array}$ \\
\hline $\begin{array}{l}\text { Organisation } \\
\text { of the courts }\end{array}$ & $\begin{array}{l}\text { Adversarial systems } \\
\text { have courts of general } \\
\text { jurisdiction available to } \\
\text { adjudicate a wide range } \\
\text { of cases. }\end{array}$ & $\begin{array}{l}\text { Civil law systems } \\
\text { tend to have } \\
\text { specialist courts } \\
\text { (and specialist } \\
\text { appeal courts) to } \\
\text { deal with } \\
\text { constitutional law, } \\
\text { criminal law, } \\
\text { administrative law, } \\
\text { commercial law, } \\
\text { and civil or private } \\
\text { law (Zweigert, } \\
1998 ; 21) .\end{array}$ \\
\hline
\end{tabular}

\section{The Judicial System in Nigeria}

Nigeria operates a federal political structure under the Constitution of the Federal Republic of Nigeria, 1999. The Federation consists of 36 (thirty six) States and a Federal Capital Territory. This constitution vests the legislative, executive and judicial powers of the Federal Republic of Nigeria in the National Assembly, the Executive and the courts established there under respectively. The powers of the States are vested in similar organs, except that the legislative organ of the States is known as the House of Assembly.

The Attorney General of the Federation and Minister of Justice is the Chief Law Officer of the Federation. He is the head of the Federal Ministry of Justice and institutes, undertakes, takes over, continues 
or discontinues criminal proceedings before courts of law in Nigeria in respect of offences created under any Act of the National Assembly. Likewise, the Attorneys General of the States have similar powers in respect of Laws enacted by the Houses of Assembly of the States. The development of the Nigerian legal system has been greatly influenced by its colonial past as a part of the British Commonwealth. The common law of England, the doctrines of equity as well as statutes of general application in force in England as at 1st January 1900 form an integral part of the laws in addition to certain English statutes that have been received into Nigerian laws by local legislation. Other sources of Nigerian law include local legislation (State and Federal), Nigerian case law as well as customary law.

The principles of judicial precedent and hierarchy of courts is also a fundamental part of Nigerian legal system with the Supreme Court of Nigeria at the apex of the court system. Nigeria operates the adversarial system of court proceedings similar to what obtains in other common law countries. However, the jury system is not used in the system of administration of justice, as the presiding judge is both a judge of the law and fact. The 1999 Constitution makes provisions for the establishment and constitution of the following courts: The Supreme Court of Nigeria, The Court of Appeal, The Federal High Court, The High Court, The Sharia Court of Appeal, The Customary Court of Appeal. There is a Customary Court of Appeal for the Federal Capital Territory and any State that requires it. This Court has appellate and supervisory jurisdiction in civil proceedings involving questions of customary law and is comprised of a President and such number of Judges as the National Assembly or the State Houses of Assembly (as the case may be) may prescribe. In addition to these courts created by the Constitution, there also exist Magistrate Courts, Disctrict Courts, Area Courts and Customary Courts established in various states by state laws. These courts are of limited jurisdiction as specified in their enabling laws and appeals from them lie to the High Court, Sharia Court of Appeal or Customary Court of Appeal as the case may be. 


\section{The Adversary Justice System in Nigeria and Beyond: A Critical Review}

Critics pose some disturbing questions about the adversary system: Is justice served by a process that is more concerned with resolving controversies than with finding the ultimate truth? Is it possible for people with limited resources to enjoy the same access to legal services as do wealthy people? Does a system that puts a premium on winning encourage chicanery, manipulation, and deception? The 1995 trial of O. J. Simpson, an actor, sportscaster, and professional football player accused of murdering his former wife and her friend, cast unprecedented scrutiny on the criminal justice system, and left many people wondering whether truth or justice play any role in its operation. Each day for over a year, the trial was televised in the homes of millions of people, most of whom had never seen the inside of a courtroom. They were fascinated and repelled by prosecutors and defense attorneys who argued relentlessly about seemingly trivial points. Even more disturbing to some viewers was the acrimonious name-calling that went on between the two sides as each attempted to discredit the other's evidence and witnesses. Likewise, the 1994 trials of Eric and Lyle Menendez, wealthy brothers who admitted killing their parents but whose first trials ended in hung juries, left many Americans bewildered and angry at a system that seemed unable to convict confessed murderers. Defense attorneys are quick to point out that the Constitution guarantees that the accused is innocent unless found guilty in a court of law, and it is impossible to protect the innocent without occasionally protecting the guilty (Kagan, 2001).

Lawyers are obligated to challenge the evidence against their clients, even if that means impugning the police or attacking a victim's or witness's character. It is their job to win an acquittal by whatever legal and ethical means within their power. Disparaging the legal system has become something of a national pastime. Indeed, criticism of the system comes from all corners of the landscape, including the top of the system itself. The late Chief Justice Warren Burger was outspoken in his lambasting of the system and of lawyers, asserting that they are too numerous and too zealous, that they file too many frivolous lawsuits and motions, and that there is general failure within the system to encourage out-ofcourt settlements. Burger was a vocal proponent of Alternative 
Dispute Resolution (ADR). He advocated the use of nonlitigious solutions such as mediation or Arbitration as a means of reducing court congestion. Supporters of the adversary system point out that it is not clear that the savings reaped from ADR always outweigh the costs. In situations where the parties are not at equal bargaining strength, questions arise as to whether settlements are extracted through duress. Some attorneys and litigants have noted that ADR is often as adversarial in nature as litigation, with evidence presented and slanted by counsel. They further complain that there is no guarantee that an arbitrator will be informed about the subject matter of the dispute, and therefore no guarantee of a fair outcome.

Without doubt, during the 1980s and 1990s, the United States experienced tremendous growth in the number of civil suits filed. The results were clogged courts, trial delays, and increased legal costs. However, the experts disagree on how to solve these problems. Critics of the system clamor for reforms to address what they perceive as its deficiencies, whereas many commentators, particularly those within the legal profession, feel that the system, although imperfect, is actually working the way it is designed to work and should not be altered. One criticism of the adversary system is that it is slow and cumbersome. The judge, acting as a neutral fact finder, can do little to accelerate a trial, and procedural and evidentiary rules further slow the process. Likewise, the wide availability of appellate review means that a final determination can take years or even decades. However, at least one study has shown that in courts where adversarial trials were discouraged and settlements actively encouraged, litigants still encountered substantial delays in resolution. And supporters of the adversary system maintain that a methodical, albeit cumbersome, system is necessary for protection of individual rights. Indeed, it is fair to challenge the ethics of a legal system that places a higher value on winning than on truth seeking (Doyle and Roger, 1991).

Commentators have characterized the system as one in which lawyers spend more time avoiding truth than seeking it. But proponents argue that the vigorous clash of opposing viewpoints eventually yields the truth, and that allowing the sides to fight it out under specific rules that guarantee fair play allows the truth to surface on its own. Many other complaints have been leveled against the adversary system. Some feel that because the parties control the 
Oraegbunam: The Jurisprudence of Adversarial Justice

litigation, they are encouraged to present only the evidence that is favorable to them and to suppress evidence that is unfavorable. Some others also feel that the lawyers' ethics code encourages zealous representation at the expense of truth, making attorneys, in the words of Burger, "hired guns" (In re Griffiths, 413 U.S. 717, 93 S. Ct. 2851, 37 L. Ed. 2d 910 [1973]. Others complain that lawyers file too many frivolous lawsuits and have become too dominant in the adversary process, like the ones filed recently by Bukola Saraki, Oliseh Metuh etc. Some even say that the rules of evidence, designed to guarantee fairness to all parties, actually work against fairness by preventing important information from being presented to the fact finder. Defenders of the adversary system are quick to refute each criticism lobbed at it. They contend that it is necessary for the parties to control the litigation in order to preserve the neutrality of the judge and jury. They point out that lawyers, although as susceptible to corruption as any other group, are governed by a code of ethical conduct that, when enforced, deals effectively with instances of overreaching. And, while conceding that evidentiary rules may be subject to manipulation, they vigorously maintain that such rules are the only means by which to ensure fairness and prevent judicial abuse (Doyle and Roger 1993).

The criticism of this legal system that may be most difficult to refute has to do with accessibility. It cannot be plausibly argued that an average criminal defendant has the same access to Legal Representation as O. J. Simpson, the wealthy Menendez brothers, the political class and the elite in Nigeria, nor can it be argued that an injured plaintiff in a civil suit is in an equal bargaining position with a huge corporation. Yet, supporters of the adversary system counter that unequal access to legal services is the result of economic and social conditions, not the structure of the legal system, and that changing the way legal services are delivered would do nothing to address the root causes of the disparity. They also point out that the much criticized contingency fee arrangement, by which an attorney is paid a percentage of the award her or his client receives, opens the courts to members of the population who could not otherwise afford legal representation, however, this sounds well in theory but challenging in praxis.

Most legal experts agree that, in the long run, the adversary system results in societal benefits that outweigh its inherent 
shortcomings. By allowing all sides of a controversy to be heard, the system protects against abuse of power, and forces those with the most at stake to focus on the issues in dispute. At its worst, it can be manipulated to the benefit of those least deserving, but at its best, it seems to offer every injured party a forum for relief, sometimes against powerful odds. No doubt, the arguments about whether and how to change the system will go on into the twenty-first century. As a system that has evolved over three hundred years, it probably will undergo some changes. But the basic values at its heart, such as Presumption of Innocence, the right to trial by jury, and protection of individual rights, appear to be firmly cemented as the cornerstones of U.S. Jurisprudence. The scheme of American Jurisprudence wherein a judge or jury renders a decision in a controversy between or among parties who assert contradictory positions during a judicial examination such as a trial, hearing, or other adjudication. U.S. courtrooms have often been compared to battlefields or playing fields. The adversary system by which legal disputes are settled in the United States promotes the idea that legal controversies are battles or contests to be fought and won using all available resources.

The contemporary Anglo-American adversary system has gradually evolved, over several hundred years. Early English jury trials were unstructured proceedings in which the judge might act as inquisitor, or even prosecutor, as well as fact finder. Criminal defendants were not allowed to have counsel, to call witnesses, to conduct cross-examination, or to offer affirmative defenses. All types of evidence were allowed, and juries, although supposedly neutral and passive, were actually highly influenced by the judge's remarks and instructions. In fact, before 1670, jurors could be fined or jailed for refusing to follow a judge's directions. The late 1600s saw the advent of a more modern adversarial system in England and its American colonies. Juries took a more neutral stance, and appellate review, previously unavailable, became possible in some cases. By the eighteenth century, juries assumed an even more autonomous position as they began functioning as a restraint on governmental and judicial abuse and corruption. The Framers of the Constitution recognized the importance of the jury trial in a free society by specifically establishing it in the Sixth Amendment as a right in criminal prosecutions. The Eight Amendment also 
established the right to a jury in noncriminal cases: In Suits at Common Law, where the value in controversy shall exceed twenty dollars, the right of trial by jury shall be preserved, and no fact tried by a jury, shall be otherwise reexamined in any Court of the United States, than according to the rules of the common law.

The independent judiciary was somewhat slower in developing. Before the 1800s, English judges were still biased by their ties with the Crown, and U.S. judges were often politically partisan. U.S. Supreme Court Chief Justice John Marshall, who served from 1801 to 1835 , established the preeminence and independence of the high court with his opinion in Marburyv Madison, 5 U.S. (1 Cranch) 137, 2 L. Ed. 60 (1803). Marbury established "the basic principle that the federal judiciary is supreme in the exposition of the law of the Constitution" (Cooper v. Aaron, 358 U.S. 1, 78 S. Ct. 1401, 3 L. Ed. 2d 5[1958]). By the early 1800s, attorneys had risen to prominence as advocates and presenters of evidence. Procedural and evidentiary rules were developed, and they turned the focus of litigation away from arguments on minute points of law and toward the resolution of disputes. The basic parameters of the United States' modern legal system had been established. The Anglo-American requirement of an impartial and passive fact finder contrasts with the requirements of other legal systems. For example, most European countries employ the Inquisitorial System, in which a judge investigates the facts, interviews witnesses, and renders a decision. Juries are not favored in an inquisitorial court, and the disputants are minimally involved in the fact-finding process. The main emphasis in a European court is the search for truth, whereas in an Anglo-American courtroom, truth is ancillary to the goal of reaching the fairest resolution of the dispute. It has been suggested that the inquisitorial system, with its goal of finding the truth, is a more just and equitable legal system. However, proponents of the adversary system maintain that the truth is most likely to emerge after all sides of a controversy are vigorously presented (Landsman, 1988).

They also point out that the inquisitorial system has its own deficiencies, including abuse and corruption. European judges must assume all roles in a trial, including those of fact finder, evidence gatherer, interrogator, and decision maker. Because of these sometimes conflicting roles, European judges might tend to prejudge 
a case in an effort to organize and dispose of it. Inquisitorial courts are far less sensitive to individual rights than are adversarial courts, and inquisitorial judges, who are government bureaucrats (rather than part of an independent judicial branch), might identify more with the government than with the parties. For Landsman (1984) critics of the inquisitorial system argue that it provides little, if any, check on government excess and that invites corruption, Bribery, and abuse of power. The adversary system has staunch defenders as well as severe critics. The image of the courtroom as a battleground or playing field where contestants vie for victory is evident in the news media's preoccupation with who is "winning" or "losing" or "scoring points" in such highly visible cases as the 1995 trial of O. J. Simpson, an actor, sportscaster, and former professional football player who was tried for killing his former wife, Nicole Brown Simpson, and her friend Ronald Goldman.

The emphasis on "winning at all costs" without commensurate concern for truth-seeking dismays some U.S. citizens, and a growing number are demanding reforms in the legal system. During the 1980s and 1990s, the use of alternative forms of dispute resolution such as mediation and Arbitration grew dramatically. However, defenders of the adversary system note that these alternatives have been used all along, in the form of settlement conferences, minitrials, and summary jury trials, and that the vast majority of lawsuits are already settled before the parties ever appear in court (Olson, 1991). When a dispute cannot be resolved without a trial, the adversary system is the established method of adjudication in the United States. Indeed, the organized bar remains committed to the notion that vigorous advocacy by both sides of a legal controversy ultimately leads the judge or jury to the facts needed for a fair resolution and that it is the process that is best calculated to elicit the truth and to protect individual rights.

\section{Concluding Remarks}

Many thanks go to the schemes, scholars and institutions that worked frenetically and succeeded in bringing about judicial systems to assist man to live sanely, peacefully and responsibly. Albeit, the next challenge is the mode of operations and hiccups that these systems encountered. However, it is instructive to take cognizance of the fact that this adversarial system like the other has evolved and 
Oraegbunam: The Jurisprudence of Adversarial Justice

developed itself over time and more of this is expected in the future. Viewed critically, neither system is inherently superior. In fact, there are many shared features and many countries incorporate features of both systems, having experienced a degree of convergence over the last 80 years (Zweigert, 1998: 271). So, as the adversarial system redefines, realigns and develops, it is good that it appreciates it strengths which includes fair hearing, the neutrality of the judge and non-interference by the government as these appears to be the major outlets of the abuses that have bedevilled the adversarial system most especially in Nigeria. Although many concede that the adversary system is imperfect and that it may be subject to abuse and manipulation, the majority still believe that, by giving all parties and their advocates the opportunity to present evidence and arguments before an impartial judge, it promotes a free and pluralistic society with the best available means of settling disputes.

*Ikenga K.E.ORAegbunaM, PhD (Law), PhD (Phil.), PhD (Rel. \& Soc.), MEd, BL, Reader and Head, Department of International Law \& Jurisprudence, Faculty of Law, Nnamdi Azikiwe University, Awka, Nigeria. ik.oraegbunam@unizik.edu.ng. 
Ogirisi: a new journal of African studies vol. 152019

\section{References}

"Appendix B: a comparison of the inquisitorial and adversarial systems". http:www//justice.govt.nz. (Sourced: 29 th $^{\text {th }}$ April, 2016).

"The adversarial system: Who wins? Who loses? http://legal/dictionary.freedictionary.com. (Sourced: 29 ${ }^{\text {th }}$ April, 2016).

Adversary System, https://en.wikipedia.org/w/index.php (Sourced 29 ${ }^{\text {th }}$ April, 2016).

Akpuru-Aja, A. 1999. Nigerian Judiciary. Abakiliki: Willrose and Appleseed Publishing Company.

Anne, Strick. 1977. Injustice for All. New York: G. P. Putnam's Sons.

Cappelletti, Mauro. 1967. The Italian Legal System. Stanford University Press.

Doyle, Stephen, and Roger Haydock. 1991. Without the Punches: Resolving Disputes Without Litigation. Minneapolis: Equilaw.

...1993. "Essays: The State of the Adversary System. 1993. Valparaiso University Law Review 27 (spring).

Jeremy, Cooper. 2010. "Poverty and Constitutional Justice". Philosophy of Law: Classic and Contemporary Readings, Larry May and Jeff Brown, UK: Wiley-Blackwell.

Kagan, Robert A. 2001. Adversarial Legalism: The American Way of Law. Cambridge, Mass.: Harvard Univ. Press.

Kagan, Robert A. 2003. Adversarial Legalism: The American Way of Law. Cambridge. MA:Harvard University Press .

Kirsten, DeBarba. 2002. "Maintaining the adversarial system: The practice of allowing jurors to question witnesses during trial". Vanderbilt Law Review. 5 (October 1): 1521-1548. 
Oraegbunam: The Jurisprudence of Adversarial Justice

Landsman, Stephan. 1984. The Adversary System: A Description and Defense. Washington, D.C.: American Institute for Public Policy Research.

Landsman, Stephan. 1988. Readings on Adversarial Justice: The American Approach to Adjudication. St. Paul, Minn.: West.

Locke John. 1960. Two Treatises of Civil Government, P. Laslett (ed.) Cambridge: CUP. New Zealand Bill of Rights Act 1990.

Olson, Walter K. 1991. The Litigation Explosion. New York: Truman Talley Books- Dutton.

Pizzi, William T, and Walter Perron. 1996. Crime Victims in German Courtrooms: A Comparative Perspective on American Problems. Stanford Journal of International Law. 32.

Posner, R. 1982. "The Constitution as an Economic Document". The George Washington Law Review, November. 56. (1).

Spencer, J R. 2002. "Evidence”. European Criminal Procedures. Delmas-Marty $\mathrm{M}$ and Spencer, J.R. Cambridge University Press.

Zweigert, K. 1998. An Introduction to Comparative Law. Clarendon Press, 3rd edition.

\section{Cases}

Cooper v. Aaron, 358 U.S. 1, 78 S. Ct. 1401, 3 L. Ed. 2d 5[1958]. 